\title{
Analysis of Tadao Ando Building Humanism
}

\author{
Haiyuan QIN \\ Civil and Architecture College \\ China Three Gorges University \\ Yichang, China \\ e-mail: 1667792481@qq.com \\ Xinyu CAO \\ Civil and Architecture College \\ China Three Gorges University \\ Yichang, China \\ e-mail: 1040772867@qq.com
}

\author{
Huayan ZHAO \\ Civil and Architecture College \\ China Three Gorges University \\ Yichang, China \\ e-mail:954010186@qq.com

\section{Long CHEN} \\ Civil and Architecture College \\ China Three Gorges University \\ Yichang, China \\ e-mail:971623427@qq.com
}

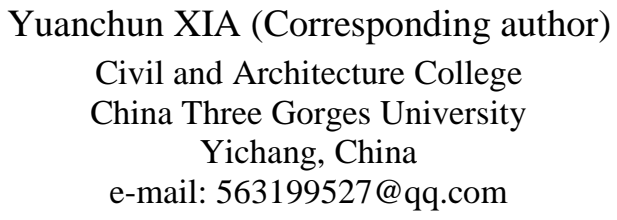

\begin{abstract}
This paper discusses Tadao Aadao's design methods to space, fair-faced concrete and light in architectural design by analyzing his representative works, meanwhile appreciating the skillfully using of the spirit of humanism in his works.
\end{abstract}

Keywords-Tadao Ando; space; fair-faced concrete; light and humanism

\section{INTRODUCTION}

Humanism was first proposed in the Renaissance period, which core ideas are sure of life, full of passion for life, and fighting for the all-round development of individual in the real world. So is how does humanism integrate into the architecture art? There is no doubt that building's designers, being filled with people-oriented thinking in the design of one building, use the architectural vocabulary to interpret their ideas to people and make humanism integrate into an art of architecture naturally. For example, Wright, in his design of Falling water, takes full account of the integration of architecture and environment. The golden section proportion in Le Corbusier's design aim is to build a link between the measure of architectural and aesthetics of the human body by the unique processing of space, materials and light, create his unique humanism aesthetics.

\section{BUILD THE ATMOSPHERE OF THE LIGHT}

Master of modern architect, Le Corbusier, once said: "Architecture is a variety of accurate, correct and excellent treatments of volume in the sun." Tadao Ando believes that light, as a carrier of the nature, can communicate with architectures and became the sole architect of space. Early Ando visited Le Corbusier's Chapelle de Ronchamp, whose highlights appearing from the dark light has a profound effect on his heart. Later, in Ando's works, his applicant of the light mostly based on a beam of light connecting with outside to create a bouquet to the light in the dark. The most classic example is the cross of light of the Church of light, whose wall is totally closed concrete, no window, and the whole environment is dull. So as to the believer can be calm here. And then in the wall behind the podium leaving two long slits, embedded glass, and outdoors light transmit from only a narrow slit into the church and become a cross of light that is the whole church's highlights. This technique is the successful work of using contrast to the deification of natural elements. The cross of light is not a specific form of material existence, but the form of light, one of the most difficult to see and touch, as I understand it is the existence of people's visual and psychological. Each person seeing it will feel shocked and moved for the building. For believers inside the church, this beam of light not only makes people feel shocked. It came with mystery, like the light of God, to lead the people's spiritual realm culminated thought, think about life here, perception of life.

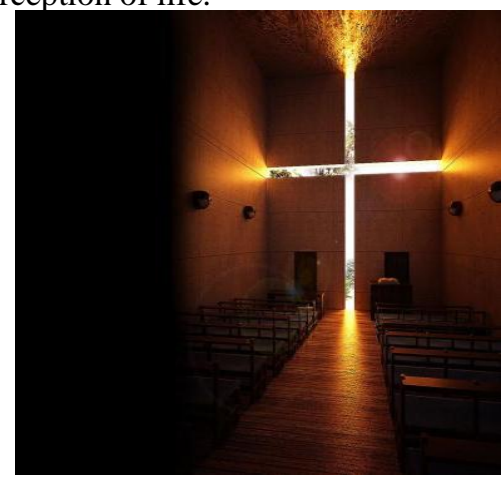

Figure 1. The light of the church of light 

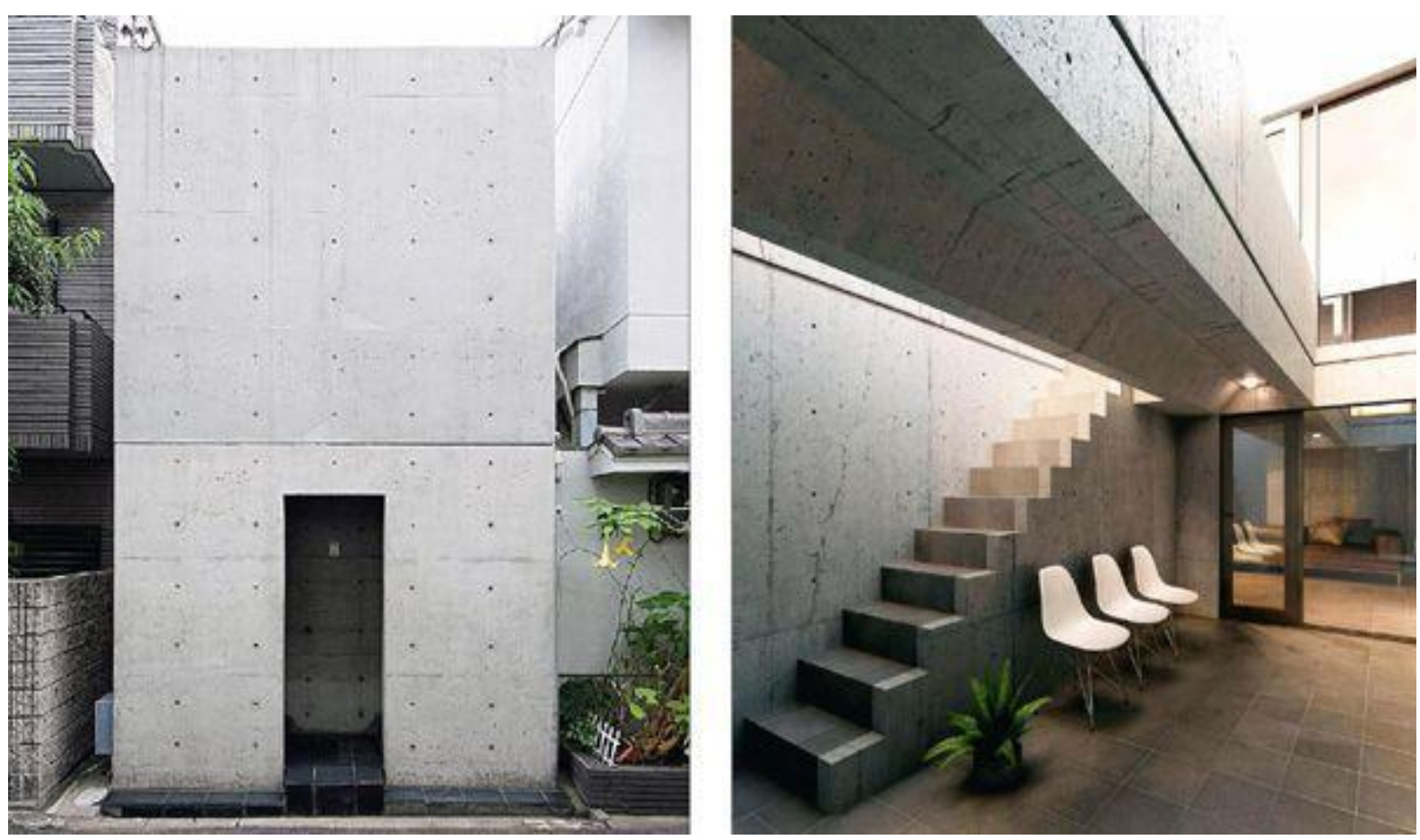

Figure 2. Azume house

\section{THE USE OF RAW MATERIALS}

The raw materials used in the building can give people a sense of stability and kinship. So Tadao Ando uses most fairfaced concrete and a small amount of wood. The reason why he selects the material of fair-faced concrete is that he just chooses the commonest and easily obtained materials and achieves the effect which others cannot obtain. Indeed, though the elaborately texture design and high quality craftsmanship, he created a unique Ando concrete with delicate and soft touch which gets rid of the rigid and rough feature. It no longer needs all kinds of complicated exterior decorations and can be used directly in the form removal, showing people the most primitive material nature. The another important reason is that the concrete slabs with heavy and solid character bring people feeling stability and security, give people hope for the future and bring them motivation to continue moving forward.

Taken Azuma House for example, fair-faced concrete as a building material gives people the lining feeling and makes us experience the concern of people from the nation of the original ecological material. Ando creates a detached house in nation in a noisy city with the use of the closed fair-faced concrete walls for owners. The concrete to give people a sense of stability and heavy feeling makes house like a matrix which give birth to a small world in surround space and then he directly introduces into a variety of natural elements combining with the inner courtyard. As a result, here becomes a living natural space where we can experience the law of natural development such as the flow of time, the change of seasons, the joys and sorrows of life and birth and death. It is not easy and valuable by a small amount of processing like this. The fair-faced concrete building of Ando, using the direct architectural language, show the architect's design language and express Japanese traditional architectural culture, aesthetic standards and the spirit of Zen. The building which is peaceful, minimalist, full of meaning delicate and precise is another natural form of existence and vaguely reveals Japanese personality of quiet and undertone.

\section{SHAPE OF THE SPACE}

Whether to extract natural elements or the original use of ecological materials, on a deeper level through these designs to create space, to create a suitable and comfortable residential building. Ando for each space is uniquely positioned to create a space and building mass to express emotions, so that people become infected, the inner space of the guide participants generate resonance sites. Learning Tadao Ando's design methods of space construction, we have to understand the Japanese how to understand spatial relationships. People talk about the relationship between interior and exterior spaces of Japanese architecture, it is vague zone between inside and outside is called "gray space", the expression of some buildings was chaotic space, perhaps the traditional Japanese way of refining and metaphorical space. So Ando's handling of space may be by its impact, the space is subtle and obscure. Tadao Ando's architectural space but always exhibit the different needs of different types of building its atmosphere, each space will make all people are infected with same architectural space psychological feelings. In Tadao Ando's architectural works mainly through the atmosphere to create a space, so that people and architectural space resonate in spirit and to exchange. People could contemplate life in the exchange, meanwhile, the subconscious feelings be stimulated. For example, the present water Mido Temple, people need to go through a 
baptism of the spirit of the pond to get to get inside the buildings. And the traveling road construction will be done in a special spatial processing, deliberately arranged in buildings flow lines, flow line be twisted and turned by Ando, so that the people live in them full of tension, but also a pleasant surprise, people can also experience and feel space content and meaning. In his architectural work, space is connected together to form a continuous, dynamic entirety.

In the design process of Mido, Tadao Ando full develops the characteristics of light, the optical material and space. He uses fair-faced concrete to set up a straight wall and an arc wall in the entrance of the building, laying pure white sand road, where the space gradually collapsed, then slowly open. There is a gradual change in the space. Visitors walking in it will feel its twists and zoom changes. Through in pure materials, only look up to see the sky above that will change, and before your eyes are a peaceful and pure landscape, then mixed feelings can calm down in this simple environment. So that people began to work hard to feel this space, in space within comprehending philosophy of life. In this building Ando use plenty of space geometry, materials and light to give a different meaning representing the cycle of change of life: death and rebirth.

Came through the front entrance of Oval pool, the huge pool symbolize life here can be bred. There plant lotus pond so that the natural changes in the seasons was added to the building, in the pool you can see the flowers blooming and
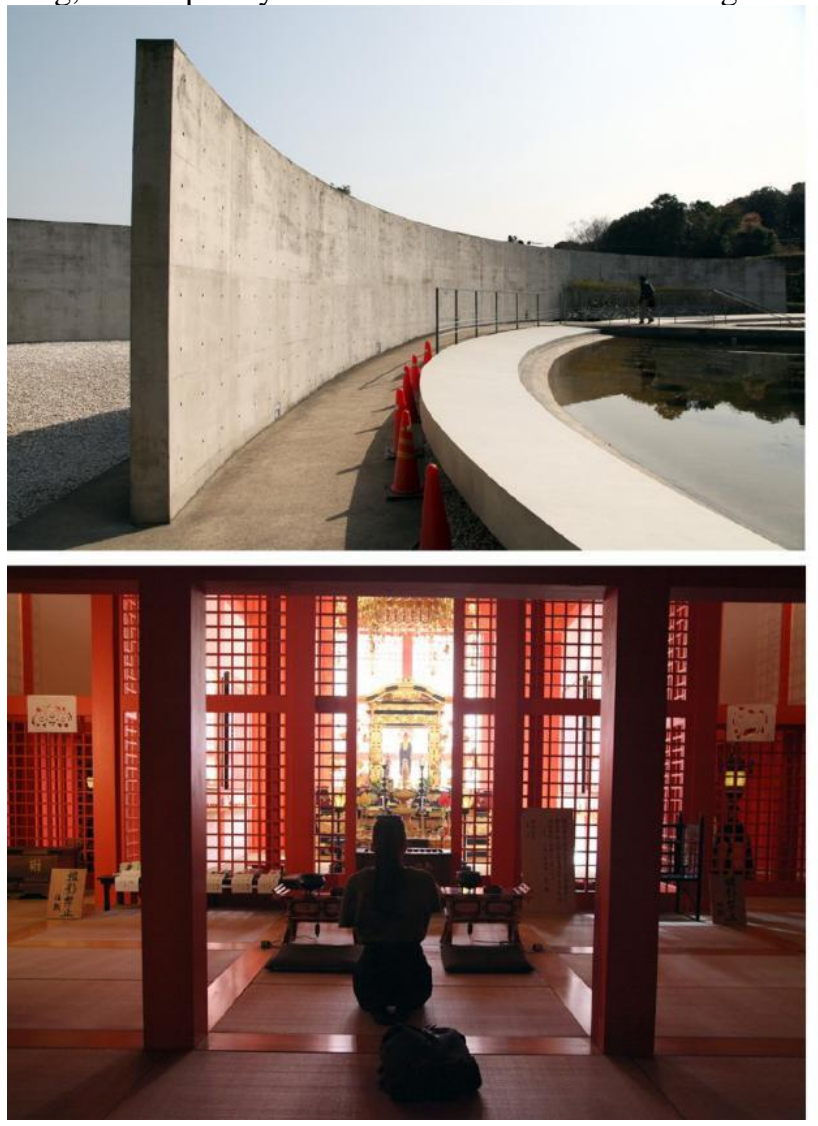

Figure 3. Oval Pool fading, as the portrayal of a person's life and death. This large pool is more like a mirror, so that visitors in front of the mirror reflect and sum up their past and think about if their own life is worth living. Then walk along the main pool hall in the middle of the narrow ladder. The light changes to dark. And light's strong changing makes people feel fear slowly. Step by step, so that feelings of loss and melancholy produce a strong sense of oppression, as psychological when face death coming slowly and this channel is a symbol of life towards to the end. When walking to Mido's main hall in the end of the channel, face a large red light, before your eyes are large and spacious shrine room for the mood suddenly pulled out from the bottom. It is similar to the joy of the sight, and then the whole world becomes very cheerful up. Here on behalf of the born again, suggesting that death is not terrible cause after experiencing a complete personal hygiene that we will be reborn again. In this whole building trip, Ando used his basic design techniques to create a period of mentality of history for people, show the essential attribute of places and convey humane care of the building at the same time, so that people here get the sentiment of the soul and felt a unique spiritual experience through his building visual space. In our design process, you can also learn to use logical organization of the design concept and strong contrast technique to show our design idea, use space shaping to show humanistic care of the building and use architectural vocabulary to convey humanist spirit that building contained.
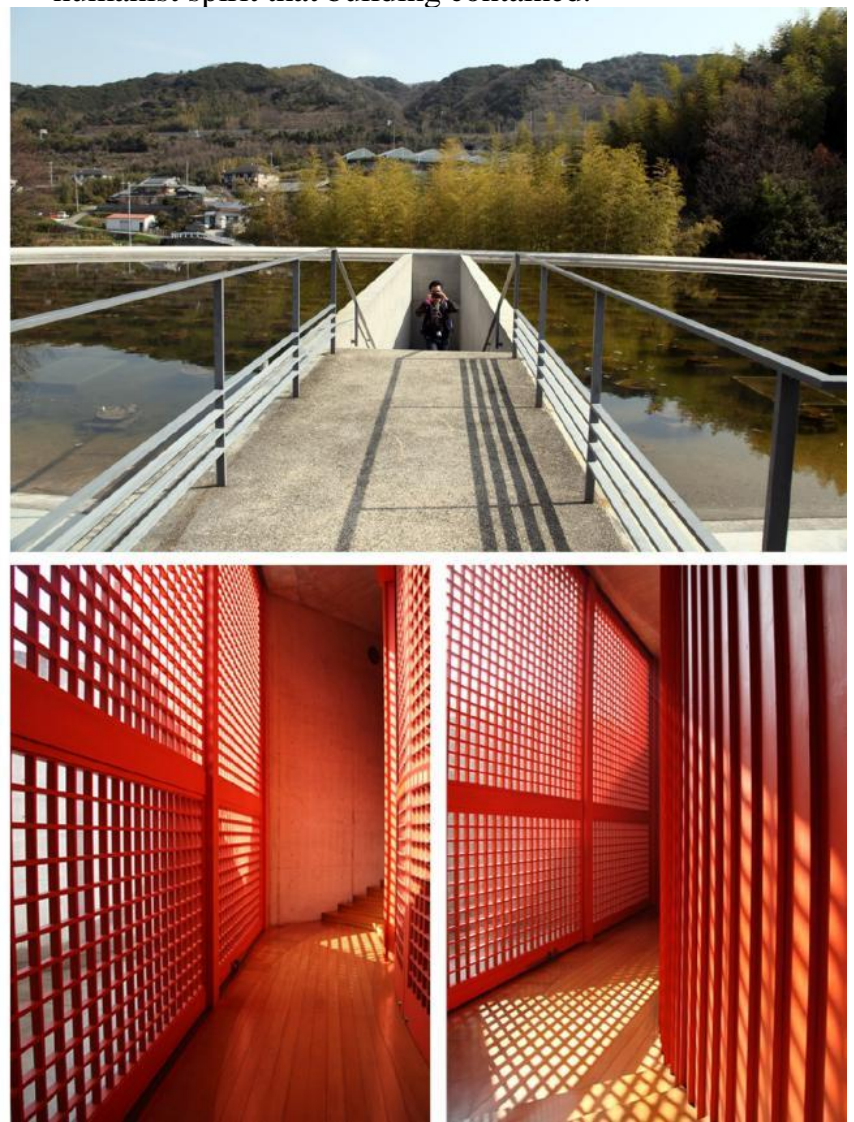


\section{CONCLUSION}

Can be seen from Ando's architectural works, whether it is the construction of light as the sole founder, or to use of fair-faced concrete cleverly, or to create a space atmosphere, are from people's mental habits and daily behavior as a starting point to carry out building artistic creation and design, from a humanistic perspective to make buildings and people live in harmony, without sacrificing either the design features of the building, nor will people put up with the architectural character design, but people have a comfortable and enjoyable to use of the building, to find spiritual sustenance in the building place. People-starting point to think about building, with people care to design the building, which Ando as a "soldier" can serve the people, but also to maintain his architectural key style. We do not have to design our own programs to pursue unconventional, truly outstanding architecture that is designed for the user of the building, rather than the design of the building to become designer's goods. In the beginning of the design program with humanistic philosophy, extract concepts from the user's needs and nature's own conditions, in-depth program on all sides in both the human-designed with the idea to think of this design is in the details Reflections on the expressed needs of users, so that the whole building on the spirit of humanism implemented.

\section{REFERENCES}

[1] Cai Jian translation of Tadao Ando Tadao Ando-Building Lecture: Lien-game losing streak CITIC Publishing House, 2014.

[2] Chen Zhihua-Foreign architectural history. China Building Industry Press, 2010. 143-196.Jeffrey Scott with. Wu Jiaqi Art translationArchitecture of Humanism Southeast University Press, 2015.

[3] Li Qing Zhi-Tadao Ando's architectural maze. People's University Press, 2008.

[4] Ma Weidong-Tadao Ando whole building. The University of Tokyo Press, 2012.

[5] Tadao Ando the White - Translated by Tadao Ando's architecture. China Building Industry Press, 2003. 